\title{
Polyphenolic compounds and essential oil analysis of selected species of the genus Thymus Analýza fenolových zložiek a analýza silice vybraných druhov rodu Thymus
}

\author{
${ }^{1}$ Comenius University in Bratislava, Faculty of Pharmacy, \\ Department of Pharmacognosy and Botany, Slovak republic \\ ${ }^{2}$ Comenius University in Bratislava, Faculty of Pharmacy, Toxicological \\ and anti-doping center, Department of Pharmaceutical \\ Analysis and Nuclear Pharmacy, Slovak republic \\ ${ }^{3}$ Plant Production Research Institute, Gene Bank of \\ The Slovak Republic, Pieštany, Slovak republic \\ Received November 30, 2014, accepted January 30, 2015
}

Kameníková M. ${ }^{\circledR}$, Fialová S. ${ }^{1}$, Ťažký A. ${ }^{2}$, Čičová I. ${ }^{3}$

${ }^{1}$ Univerzita Komenského v Bratislave, Farmaceutická fakulta, Katedra farmakognózie a botaniky, Slovenská republika ${ }^{2}$ Univerzita Komenského v Bratislave, Farmaceutická fakulta, Toxikologické a antidopingové centrum, Katedra farmaceutickej analýzy a nukleárnej farmácie, Slovenská republika

${ }^{3} V y ́ s k u m n y ́$ ústav rastlinnej výroby, Génová banka, Pieštany, Slovenská republika

Abstract The content of phenolic compounds (total phenolic compounds, tannins, flavonoids and anthocyanidins) of three species of thyme (Thymus pulegioides, Thymus pannonicus, Thymus praecox) of different origin (Bohemian-Moravian highlands, Křivoklát and Považský Inovec) was determined using spectrophotometric methods of European Pharmacopoeia $8^{\text {th }}$ edition. Furthermore, the determination of the content of essential oil and analysis of its constituents was realised. The amount of total phenolics was determined by a spectrophotometric method using the Folin-Ciocalteu reagent. Their content ranged from 3.87 to $8.86 \%$. The content of tannins was established on a preliminary determination of the total phenolics, followed by adsorption of tannins on hide powder. The amount of tannins in our samples varied from 1.96 to $5.65 \%$. The content of total flavonoids was determined by a spectrophotometric method using aluminium chloride. Quantitative analysis of flavonoids has shown that content in our samples ranged from 0.59 to $1.52 \%$ expressed as luteolin-7-O-glucoside $(\lambda=392 \mathrm{~nm})$ and from 0.41 to $1.12 \%$ expressed as rutin $(\lambda=420 \mathrm{~nm})$. Anthocyanins represent a small amount of total polyphenol content in Thymus species. In our samples, the content of anthocyanins expressed as cyanidin-3-O-glucoside varied from 0.02 to $0.1 \%$. The determination of essential oil was realised by method of European Pharmacopoeia $8^{\text {th }}$ edition. Its contents in our samples ranged from 0.2 to $0.75 \%$. Gas chromatography-mass spectrometry was used for essential oil analysis. According to the presence of main monoterpene in Thymus essential oil, we can distinguish three chemotypes: thymol, carvacrol and linalool. Due to variations of chemical constituents of thyme essential oil, it was possible to observe a relationship between occurrence of certain chemotype and origin of sample. Differences in content of flavonoids have not shown a significant relationship to locality of origin.

Slovak Predložená práca bola zameraná na stanovenie obsahu vybraných fenolových zlúčenín (celkové fenoly, triesloviny, flavonoidy a abstract antokyány) troch rôznych druhov rodu Thymus (T. pulegioides, T. pannonicus, T. praecox) s rozdielnym pôvodom (Českomoravská vrchovina, Křivoklát a Považský Inovec). Na stanovenie týchto zložiek boli využité spektrofotometrické metódy Európskeho liekopisu, 8. vydanie. Zároveň bol stanovený aj obsah silice a bola vykonaná analýza jej zložiek. Obsah celkových polyfenolov bol stanovený spektrofotometrickou metódou s využitím Folin-Ciocalteovho činidla. Obsah kolísal od $3.87 \%$ do 8,86 \%. Obsah trieslovín bol realizovaný na základe predošlého stanovenia obsahu celkových fenolov, a to adsorpciou trieslovín na kožný prášok. Ich obsah sa pohyboval v rozmedzí 1,96\% do 5,65\%. Na stanovenie obsahu flavonoidov bola využitá spektrofotometrická metóda s chloridom hlinitým. Obsah flavonoidov vyjadrených ako luteolín-7-O-glukozid $(\lambda=392 \mathrm{~nm})$ kolísal od 0,59 \% do 1,52 $\%$ a obsah flavonoidov vyjadrených ako rutín $(\lambda=420 \mathrm{~nm})$ sa pohyboval v rozmedzí od $0,41 \%$ do $1,12 \%$. Antokyány zaberajú v rámci fenolových zložiek rodu Thymus len minimálny podiel. V našich vzorkách bol obsah antokyánov vyjadrený ako cyanidín-3O-glukozid a kolísal od 0,02 \% do 0,1 \%. Na stanovenie obsahu silice bola využitá metóda Európskeho liekopisu, 8.vydanie. Obsah silice sa pohyboval v rozmedzí od $0,2 \%$ do $0,75 \%$. Na analýzu silice bola následne využitá metóda plynovej chromatografie s hmotnostnou spektrometriou. Na základe tejto analýzy bola zistená prítomnost' troch chemotypov silice, a to tymolového, karvakrolového a linaloolového chemotypu. Vd’aka variáciami chemického zloženia silice, bolo možné pozorovat' vztahah medzi prítomnostou určitého chemotypu a pôvodom vzorky. Rozdiely v stanovení obsahu flavonoidov nepreukázali žiadny výrazný vztah k lokalite pôvodu.

Keywords Thymus L. - phenolic compounds-essential oil-flavonoids

Klúčové Thymus L. - fenolové zlúčeniny - silica - flavonoidy

slová:

*E-mail:mirka.kamenik@gmail.com

( ) Acta Facultatis Pharmaceuticae Universitatis Comenianae 


\section{INTRODUCTION}

The genus Thymus is considered to be one of the largest and most important in Lamiaceae family. The number of species in this genus is debatable and from taxonomical point of view, it often varies. The estimated number of species is above 200. The genus is spread around the whole world. In Slovakia, it can be found seven species, namely, Thymus pulegioides, $T$. alpestris, T. pannonicus, T. glabrescens, T. praecox, T. pulcherrimus and T. serpyllum (Bertová, 1993). Currently, the presence of $T$. alternans KLOKOV has been also documented, which would present the $8^{\text {th }}$ species. It was found in hills of northeastern Slovakia (Martónfy, 1996). Active compounds of thyme can be divided in the two main classes of secondary products, the volatile essential oil and the polyphenols, among which flavonoids are the most occurring. Both secondary metabolites are mainly responsible for the pharmacological activity of Thymus plants (Van den Broucke, 1983; Stahl-Biskup, 2002). The essential oil stored in glandural peltate trichomes situated on both sides of the leaves is responsible for the typical spicy aroma of thyme. Most of the volatiles detected in thyme oil belong to the monoterpene group. The main representative monoterpenes are thymol, carvacrol, linalool, $p$-cymene and $\gamma$-terpinene (Stahl-Biskup, 2004).

Concerning flavonoids, their presence in the genus was found mostly in the form of aglycones. Among the aglycones, that have been described thus far, luteolin and apigenin are the most frequently occurring.

Anthocyanidins have barely been found in the genus Thymus, the anthocyanidin cyanidin being the only one reported (Stoess, 1972).

The uses of Thymus species are well known and can be divided into medicinal and non-medicinal. With regard to the medicinal use, thyme is known to possess antibacterial, antifungal, spasmolytic and antioxidant properties, so it can be used as supportive treatment for various respiratory and gastrointestinal diseases. Furthermore, antiparasitic and insecticidal effects of thyme have been reported. Concerning non-medicinal use, thyme is used as a food preservative and as a spice in Mediterranean kitchen. Thyme oil is also used in many cosmetic preparations, such as deodorants, toothpastes and mouthwashes (Zarzuelo \& Crespo, 2002).

\section{MATERIAL AND METHODS}

\section{Plant material}

Investigated plants originated from different areas of Slovakia and Czech Republic. Then, they were cultivated and harvested in Gene Bank of Plant Production Research Center in Pieštany. The aerial parts of plants were harvested by hand at the time of early flowering (June-July). Harvested material was dried at room temperature. Our investigated plant material was represented by three species namely; T. pannonicus, T. praecox and T. pulegioides.<smiles>Cc1ccc(C(C)C)c(O)c1</smiles>

Thymol<smiles>Cc1ccc(C(C)C)cc1O</smiles>

Carvacrol<smiles>C=CC(C)(O)CCC=C(C)C</smiles>

Linalool
Figure 1. The most frequently occurring monoterpenes of thyme<smiles></smiles><smiles>O=c1cc(-c2ccc(O)cc2)oc2cc(O)cc(O)c12</smiles>

Apigenin

Figure 2. The most frequently occurring flavonoids of thyme

Methods (European Pharmacopoeia, 8. edition)

Total phenolic and tannins contents (spectrophotometric assay)

The amount of total phenolics was determined by a spectrophotometric method using the Folin-Ciocalteu reagent (Spectrophotometer Genesys 6, Thermo Electron Corporation, UK). The content of tannins was based on a preliminary determination of the total phenolics, followed by adsorption of tannins on hide powder. Subsequently, the polyphenols remaining in solution were quantitatively determined. Tannins were determined by difference.

Flavonoids (spectrophotometric assay)

The content of total flavonoids was determined by a spectrophotometric method using aluminium chloride (Spectrophotometer Genesys 6, Thermo Electron Corporation, 
Polyphenolic compounds and essential oil analysis of selected species of the genus Thymus

Table 1. Taxon and origin of samples

\begin{tabular}{|c|c|c|c|}
\hline Sample & Species of Thymus & Origin & Altitude [m] \\
\hline T 15 & T.pulegioides & Bohemian-Moravian Highlands & 620 \\
\hline T 16 & T.pulegioides & Bohemian-Moravian Highlands & 660 \\
\hline T 17 & T.pulegioides & Bohemian-Moravian Highlands & 630 \\
\hline T 18 & T.pulegioides & Bohemian-Moravian Highlands & 410 \\
\hline T 19 & T.pulegioides & Bohemian-Moravian Highlands & 420 \\
\hline T 20 & T.pulegioides & Bohemian-Moravian Highlands & 283 \\
\hline T 21 & T.praecox & Křivoklát & 340 \\
\hline T 22 & T.praecox & Křivoklát & 400 \\
\hline T 23 & T.praecox & Křivoklát & 415 \\
\hline T 24 & T.pulegioides & Křivoklát & 250 \\
\hline T 25 & T.pannonicus & Bohemian-Moravian Highlands & 447 \\
\hline T 26 & T.pulegioides & Považský Inovec & 297 \\
\hline T 27 & T.pulegioides & Považský Inovec & 407 \\
\hline T 28 & T.pulegioides & & \\
\hline
\end{tabular}

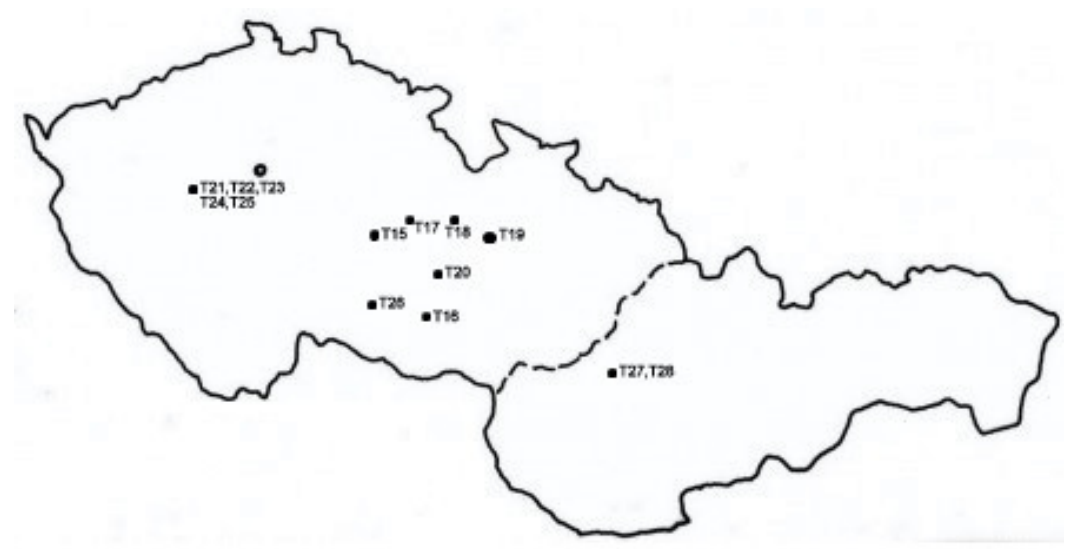

Figure 3. Geographic origin of samples

UK). The percentage contents were calculated and expressed as luteolin-7-O-glucoside $(\lambda=392)$ and rutin $(\lambda=420)$.

\section{Anthocyanins (spectrophotometric assay)}

The content of anthocyanins was determined by a spectrophotometric method (Genesys 6, Thermo Electron Corporation UK). The percentage contents were calculated and expressed as cyanidin-3-glucoside $(\lambda=528)$.

\section{Essential oil (hydrodistillation)}

The determination of essential oil: $20.0 \mathrm{~g}$ of cut drug and 500 $\mathrm{ml}$ of distilled water as the distillation liquid were used for the distillation. Distillation was provided at a rate of $2-3 \mathrm{ml} / \mathrm{min}$ for $2 \mathrm{~h}$.
Essential oil analysis by GC-MS

For essential oil analysis gas chromatography-mass spectrometry - GC-MS (GC: Thermo Finnigan; MS: Trace DSQ) a column HP - 20M Carbowax ( $0.2 \mu$ m thickness, 20 m length) was used. The column temperature was $40^{\circ} \mathrm{C}$. Helium with flow rate $0.5 \mathrm{ml} \mathrm{min} \mathrm{m}^{-1}$ was used as a carrier gas. Aliquots of $1 \mu \mathrm{L}$ were analysed. The temperature of injector was $240^{\circ} \mathrm{C}$. For ion separation, quadrupole mass filter (QMS) was used. Mass spectra were determined in a range from 20 to 300 $\mathrm{m} / \mathrm{z}$. Qualitative evaluation was determined according to obtained mass spectra, which were identified by NIST spectra database. 


\section{RESULTS}

Table 2. The contents of essential oil and phenolic compounds [\%]

\begin{tabular}{|c|c|c|c|c|c|c|}
\hline Sample & $\begin{array}{c}\text { Essential oil } \\
\text { [\%] }\end{array}$ & $\begin{array}{c}\text { Total } \\
\text { polyphenols } \\
{[\%]}\end{array}$ & $\begin{array}{c}\text { Tannins } \\
\text { [\%] }\end{array}$ & $\begin{array}{c}\text { Flavonoids (as } \\
\text { luteolin-7-O- } \\
\text { glucoside) [\%] }\end{array}$ & $\begin{array}{c}\text { Flavonoids (as } \\
\text { rutin) }[\%]\end{array}$ & $\begin{array}{c}\text { Anthocyanins } \\
\text { (as cyanidin-O- } \\
\text { glucoside) [\%] }\end{array}$ \\
\hline T 15 & $0.50 \pm 0.01$ & $3.88 \pm 1.07$ & $3.12 \pm 0.82$ & $0.71 \pm 0.05$ & $0.83 \pm 0.02$ & $\mathbf{0 . 1 0} \pm \mathbf{0 . 0 4}$ \\
\hline T 16 & $0.40 \pm 0.01$ & $7.61 \pm 0.30$ & $4.84 \pm 0.09$ & $0.99 \pm 0.04$ & $\mathbf{1 . 1 2} \pm \mathbf{0 . 0 3}$ & $0.09 \pm 0.03$ \\
\hline T 17 & $0.50 \pm 0.01$ & $\mathbf{8 . 8 6} \pm \mathbf{0 . 2 3}$ & $5.45 \pm 0.28$ & $\mathbf{1 . 5 2} \pm \mathbf{0 . 0 6}$ & $1.08 \pm 0.03$ & $0.08 \pm 0.03$ \\
\hline T 18 & $0.60 \pm 0.02$ & $7.25 \pm 0.56$ & $4.62 \pm 0.64$ & $0.97 \pm 0.02$ & $0.78 \pm 0.01$ & $0.08 \pm 0.03$ \\
\hline T 19 & $0.30 \pm 0.00$ & $5.95 \pm 0.28$ & $4.14 \pm 0.61$ & $1.14 \pm 0.05$ & $0.81 \pm 0.03$ & $0.09 \pm 0.04$ \\
\hline T 20 & $0.50 \pm 0.01$ & $6.52 \pm 0.25$ & $3.48 \pm 0.50$ & $0.86 \pm 0.04$ & $0.73 \pm 0.04$ & $0.07 \pm 0.02$ \\
\hline T 21 & $0.70 \pm 0.02$ & $7.62 \pm 0.52$ & $4.77 \pm 0.74$ & $0.59 \pm 0.03$ & $0.54 \pm 0.02$ & $0.07 \pm 0.03$ \\
\hline T 22 & $0.70 \pm 0.01$ & $5.90 \pm 0.07$ & $3.64 \pm 0.23$ & $0.94 \pm 0.07$ & $0.59 \pm 0.03$ & $0.08 \pm 0.03$ \\
\hline T 23 & $0.20 \pm 0.00$ & $4.81 \pm 1.05$ & $3.08 \pm 1.00$ & $1.12 \pm 0.07$ & $0.41 \pm 0.02$ & $0.07 \pm 0.01$ \\
\hline T 24 & $0.60 \pm 0.01$ & $4.66 \pm 0.49$ & $3.33 \pm 0.54$ & $0.93 \pm 0.06$ & $0.82 \pm 0.03$ & $0.05 \pm 0.02$ \\
\hline T 25 & $\mathbf{0 . 7 5} \pm \mathbf{0 . 0 2}$ & $7.35 \pm 0.23$ & $\mathbf{5 . 6 5} \pm \mathbf{0 . 2 7}$ & $1.16 \pm 0.06$ & $0.80 \pm 0.03$ & $0.05 \pm 0.02$ \\
\hline T 26 & $0.45 \pm 0.01$ & $4.99 \pm 0.89$ & $2.80 \pm 0.40$ & $1.03 \pm 0.04$ & $0.81 \pm 0.02$ & $0.05 \pm 0.03$ \\
\hline T 27 & $0.30 \pm 0.00$ & $3.87 \pm 0.21$ & $1.96 \pm 0.23$ & $0.81 \pm 0.05$ & $0.57 \pm 0.03$ & $0.01 \pm 0.00$ \\
\hline T 28 & $0.20 \pm 0.00$ & $7.13 \pm 0.78$ & $4.72 \pm 0.37$ & $0.65 \pm 0.26$ & $0.43 \pm 0.13$ & $0.05 \pm 0.02$ \\
\hline
\end{tabular}

Table 3. Chemical composition of essential oil

\begin{tabular}{|c|c|c|c|c|c|c|c|c|c|c|c|c|c|c|}
\hline Compound & T15 & T16 & T17 & T18 & T19 & T20 & T21 & T22 & T23 & T24 & T25 & T26 & T27 & T28 \\
\hline Thymol & - & 0.7 & - & - & - & 0.6 & 44.3 & 7.9 & 8.1 & 54.8 & 1.2 & 4.8 & 1.18 & 0.6 \\
\hline Carvacrol & 56.0 & 31.1 & 30.7 & 26.2 & 0.8 & 0.6 & 2.8 & 38.7 & & 13.4 & 50.1 & 2.2 & 5.5 & 0.4 \\
\hline m-cymene & 7.2 & 7.2 & 4.2 & 3.6 & 0.5 & - & 19.3 & - & 3.8 & 10.1 & 16.9 & - & 0.5 & - \\
\hline$\beta$-linalool & 6.3 & - & - & - & 11.4 & 35.7 & 2.9 & 4.7 & - & 0.2 & - & 26.4 & 40.9 & 27.1 \\
\hline $\begin{array}{c}\text { Thymyl methyl } \\
\text { ether }\end{array}$ & 20.8 & 1.8 & 8.2 & 5.6 & 0.4 & - & - & 7.1 & - & 2.0 & 6.3 & - & 1.1 & - \\
\hline $\boldsymbol{\gamma}$-terpinene & 5.0 & 6.4 & 3.9 & 8.0 & - & - & 5.9 & 16.0 & 1.6 & 8.0 & 11.2 & - & 0.5 & - \\
\hline Caryophyllene & 3.5 & 2.3 & 3.5 & 0.4 & - & - & - & - & 1.7 & - & 4.2 & 4.8 & 2.7 & 5.7 \\
\hline Epizonarene & - & - & - & - & - & - & - & - & 10.4 & - & - & - & - & - \\
\hline Patchoulene & - & 2.1 & 5.5 & 1.7 & 1.1 & 8.3 & 2.0 & 0.9 & - & 2.0 & - & - & - & - \\
\hline Cis-geraniol & - & - & 7.7 & - & - & 2.8 & - & - & - & - & - & 3.7 & 1.4 & 2.5 \\
\hline Carveol & - & - & - & - & - & 8.7 & - & - & - & - & - & - & - & 8.7 \\
\hline o-cymene & - & - & - & - & - & - & - & 13.3 & - & - & - & - & - & - \\
\hline a-himachalene & - & - & - & - & - & - & - & - & - & - & 3.4 & 11.5 & - & - \\
\hline$\beta$-citral & - & - & - & - & - & - & - & - & - & - & - & 9.6 & 3.9 & 8.3 \\
\hline Citral & - & - & - & - & - & - & - & - & - & - & - & 14.0 & 5.8 & 11.4 \\
\hline Trans-geraniol & - & - & - & - & - & - & - & - & - & - & - & 10.6 & 3.7 & 4.7 \\
\hline (-)- $\boldsymbol{\beta}$-bisabolene & - & - & - & - & - & - & - & - & - & - & - & - & 19.6 & 23.6 \\
\hline
\end{tabular}




\section{DISCUSSION}

This study was aimed to evaluate the contents of phenolic compounds of 14 samples with different origin of thyme. Furthermore, determination and analysis of essential oil was realised. Phenolic compounds possessing one or more aromatic rings bearing one or more hydroxyl groups with over 8000 structural variants and generally are categorised as phenolic acids and derivatives, flavonoids, tannins, stilbenes, curcuminoids, coumarins, lignans, quinones, and others based on the number of phenolic rings and of the structural elements that link these rings (Fresco P, Borges F, Diniz C, Marques MPM, 2006).

Determined total phenolic amounts as estimated by the Folin-Ciocalteu colorimetric method revealed that Thymus species exhibited high variable contents ranging from $3.87 \pm$ 0.21 (T27) to $8.86 \pm 0.23 \%$ (T17). Among phenolic compounds the content of tannins, flavonoids and anthocyanins was determined. Tannins in Lamiaceae family are represented by glycosides or depsides of hydroxycinnamic acid derivatives (Nagy, Mučaji, Grančai, 2011).The tannins in the genus Thymus are mainly represented by rosmarinic acid, a depside of caffeic acid and dehydrocaffeic acid. The quantitative data of the content of rosmarinic acid in the literature vary owing to the different analytical methods applied for quantification (StahlBiskup, 2004). The content of tannins in our samples ranged from 1.96 to $5.65 \%$. Quantitative analysis of flavonoids has shown that content in our samples ranged from $0.59 \pm 0.03$ to $1.52 \pm 0.06 \%$ expressed as luteolin-7-O-glucoside $(\lambda=392$ $\mathrm{nm})$ and from $0.41 \pm 0.02$ to $1.12 \pm 0.03 \%$ expressed as rutin $(\lambda=420 \mathrm{~nm})$. With regard to our results, there is no significant correlation between content of flavonoids and origin of samples and therefore, more studies concerning not only a content of flavonoids, but also their structural identification should be done. Phytochemical analysis of other studies has revealed relationships among flavonoid profiles, morphology and locality (Horwath et al., 2008). Anthocyanins are phenolic compounds, which are responsible for the primary red and blue pigments in plants. Recently, they have been shown to act as antioxidants, allowing for their potential use as a medicinal agent and as a food additive. Anthocyanins represent a small amount of total polyphenol content in Thymus species. In our samples, the content of anthocyanins varied from 0.02 to $0.1 \%$. With regard to essential oil, its content in our samples ranged from 0.2 to $0.75 \%$. Three chemotypes of essential oil were detected namely; thymol, carvacrol and linalool chemotype. Based on our results, it is obvious that carvacrol was present as the main compound in samples originated from higher altitude (>450 m) and a cooler climate with higher humidity (Bohemian-Moravian highlands). Thymol and linalool chemotypes of essential oil occurred in a lower altitude $(<$ $450 \mathrm{~m}$ ) with drier climate (Křivoklát and Považský Inovec). Sample T23 contained as a main compound sesquiterpene epizonarene, which presents an atypical chemical structure for the genus Thymus. It is possible that epizonarene presents a degradation product of germacrene $D$, which is one of the 34 most commonly occurring terpenes of thyme essential oil (Bülow, König, 2000). On the other hand, also genetic variations of the samples have to be considered. With regard to our samples, T. pulegioides contained both phenolic and non-phenolic chemotypes of essential oil, while T. pannonicus and T. praecox contained only phenolic chemotypes of thyme oil.

\section{CONCLUSION}

On the presented results, we confirmed high chemical variability of the genus Thymus, which varies due to intrinsic and extrinsic factors, though more studies are required to find out clear relationships between environmental conditions and chemical variations of specific species.

\section{ACKNOWLEDGEMENT}

The plant material for this study was provided by The Plant Production Research Center in Pieštany. This work was supported by the grants projects VEGA1/0059/11.

\section{References}

[1] Bertová L. Flóra Slovenska 5.1. Bratislava: Veda; 1993.

[2] Bülow N, König WA. The role of germacrene D as a precursor in sesquiterpene biosynthesis: investigations of acid catalyzed, photochemically and thermally induced rearrangements. Phytochemistry. 2000;55:141-168.

[3] Council of Europe. European Pharmacopoeia, 8. edition (Ph.Eur. 8). Strasbourg: Council of Europe, 2014.

[4] Čičová I, Fialová S, Cupaková M, Ťažký A, Hauptvogel P, Grančai D. Morphological and chemical investigations of the genetic resources of Thymus species. Acta fytotechnica et zootechnica. 2011;14:19-23.

[5] Fialová S, Čičová I, Kameníková M, Eliáš P, Taž̌ký A, Grančai D. Taxa variability of the genus Thymus $L$. from the essential oil composition point of view (in Slovak). Hodnotenie genetických zdrojov rastlín pre výživu a pol'nohospodárstvo. 2013;28-32.

[6] Fresco P, Borges F, Diniz C, Marques MPM. New insights on the anticancer properties of dietary polyphenols. Med Res Rev. 2006;26:747-766.

[7] Horwath AB, Grayer RJ, Keith-Lucas M, Simmonds MSJ. Chemical characterisation of wild populations of Thymus from different climatic regions in southeast Spain. Biochem. Syst. Ecol. 2008;36:117-133.

[8] Mártonfi P. Polymorphism of Essential Oil in Thymus pulegioides subsp. Chamaedrys in Slovakia. J Essent Oil Res. 1991;4:173-179.

[9] Mártonfi P. Thymus alternans KLOLKOV - a new species of Slovak flora. Biologia. 1996;51:27-29. 
[10] Mechtler C, Scheider A, Langer R, Jurenitsch J. Intraindividuelle variabilitat der zusammensetzung des atherischen oles von Quendel-arten. Sci Pharm. 1994;62:117.

[11] Nagy M, Grančai $D$, Mučaji P. Farmakognózia. Biogenéza prírodných látok, $1^{\text {st }}$ edition. Martin: Osveta; 2011.

[12] Peter KV. Handbook of Herbs and Spices. Cambridge: Woodhead Publishing; 2004.

[13] Stahl-Biskup, E. The Genus Thymus. New York: Taylor \&Francis Inc; 2002.
[14] Stoess G. Phytochemische und Physiologische Untersuchungen über Polyphenole in Thymus vulgaris L, und Thymus pulegioides L.[dissertation]. München; 1972.

[15] Trease GE, Evans WC. Pharmacognosy, 15th Edition. London: WB Sauners; 2002.

[16] Van Den Broucke CO. The therapeutic value of Thymus species. Fitoterapia. 1983;54:171-174.

[17] Zarzuelo A, Crespo E. The medicinal and non-medicinal uses of thyme. In:The Genus Thymus. New York:Taylor \&Francis Inc; 2002. 